\title{
Government and Aesthetic Beauty Clinic's Responsibility in Fulfilling the Citizens' Constitutional Right to the Service of Aesthetic Beauty Clinic in Indonesia
}

\author{
Siska Diana Sari ${ }^{1 *}$, I Gusti Ayu Ketut Rachmi Handayani ${ }^{1}$ and Pujiyono ${ }^{1}$ \\ ${ }^{1}$ Faculty of Law, Sebelas Maret University, Surakarta, Indonesia
}

\begin{abstract}
This article studies the government and the esthetic beauty clinic's responsibility in fulfilling the citizens' constitutional right in the service of esthetic beauty clinic in Indonesia. The research method is empirical qualitative to the stakeholders of esthetic beauty clinics in ten cities in Indonesia. The result of the research shows that those responsible for fulfilling the citizens' constitutional right to the service of Esthetic Beauty Clinic in Indonesia are public and private. The government's responsibility has been mentioned in Article 28D, clause (1) of 1945 Constitution concerning the right to guaranty, law protection and certainty and Article $28 \mathrm{H}$ clause (1) related to the right to health and to get healthcare service. The rights fulfillment is accomplished using the legal instrument and the institution of state authorized in licensing, organization, building, supervision, monitoring, and evaluation in the organization of esthetic beauty clinic. The esthetic beauty clinic' responsibility includes: fault, risk, product, and professional. These responsibilities have not been fulfilled maximally yet because some law infringements are still found, so the government's intervention should be optimized with the protection of beauty clinic users' constitutional rights from upstream to downstream and the regulation as well as the authorized institution should be harmonized.
\end{abstract}

\section{Introduction and Literature Review}

The rights to law protection, health, and healthcare service are constitutional ones. These have been mandated in Article 28D clause 1 of Republic of Indonesia's 1945 Constitution mentioning that "Every person shall have the right of recognition, guarantees, protection and certainty before a just law, and of equal treatment before the law" and Article $28 \mathrm{H}$ clause 1 mentioning that "Every person shall have the right to live in physical and spiritual prosperity,

\footnotetext{
${ }^{*}$ Corresponding email: siskadianasari@ymail.com
} 
to have a home and to enjoy a good and healthy environment". Article 9 clause 3 of Law Number 39 of 1999 about Human Rights mentions that "Every person shall have the right to have good and healthy environment" [1]. Article 7 of Law Number 36 of 2009 about Health states that government is in charge of organizing healthcare attempt that is distributed evenly and affordable to the people and Article 4 states that every person shall have right to be healthy [2].The importance of health as human right has been recognized internationally in Universal Declaration of Human Rights (UDHR) Article 25 clause (1) that mentions 'Everyone has the right to a standard of living adequate for the health and well-being of himself and of his family, including food, clothing, housing and medical care and necessary social services, and the right to security in the event of unemployment, sickness, disability, widowhood, old age or other lack of livelihood in circumstances beyond his control', (2) 'Motherhood and childhood are entitled to special care and assistance'. All children, whether born in or out of wedlock, shall enjoy the same social protection [3].

The guarantee of health right is also mentioned in Article 12 clause (1) of International Covenant on Economic, Social and Cultural Rights adopted and opened for signature, ratification and accession by General Assembly resolution 2200A (XXI) of 16 December 1966, stating that The States Parties to the present Covenant recognize the right of everyone to the enjoyment of the highest attainable standard of physical and mental health [4].

The fulfillment of constitutional rights is inseparable from dynamic globalization, development constituting something inevitable to many nations/states in the world, including Indonesia. Everything occurring in globalization affects the fulfillment of such right; the more the development, the more is the demand for the right fulfillment. Globalization is a global life aspect in which the link becomes borderless and patients (consumers) are increasingly interested in being more involved in decisions about their health and increasingly search for online health information [5]. One of the globalization impacts is a culture and lifestyle, including self-treatment for both men and women, and it is welcomed and read by investors to utilize this self-treatment predisposition by opening beauty clinic [6].

The users of aesthetic beauty clinic are the party that should be protected by the rights of constitutional referred to as a patient or consumer health, because getting health services and products and services at the clinic. According to Black's Law Dictionary, the consumer is a person who buys goods or service for personal, family, or house-hold use, user that has no intention to use the product or resale; a natural person who use product for personal rather than business purpose [7]. Whereas in the Text Books on Consumer Law, the consumer is the one who purchase goods or service. The definition requires that the consumer is any person or individual who is to be protected as long as it doesn't have the capacity and acting as manufacturers and businessmen [8].

Various efforts are undertaken, including plastic surgery that is currently also available in aesthetic beauty clinics. Plastic surgeons are called upon to perform aesthetic surgery on patients of every gender, race, lifestyle, and religion. Currently, it may seem natural that cosmetic surgery should be perceived as permissible, and in our modern liberal age, it seems strange to attempt justifying certain surgical acts in the light of a particular cultural or religious tradition [9].

Beauty treatment means a business dealing with cosmetic treatments for men and women which is from the hair to the toes. Other variations of this type of business are including hair salons and spas. A beauty salon has become an almost iconic image in life culture. It is a place where people go for a beauty treatment and to purchase a beauty product. A beauty salon is also a center for community news and confessions. Each salon tries to have its own distinct identity and ambiance [10]. 


\subsection{Beauty Clinic in Indonesia}

Beauty clinic is a means of inpatient healthcare service providing medical services (consultation, examination, treatment, and medical action) to deal with some conditions/diseases related to an individual's beauty (appearance esthetics), operated by medical workers (physician, dentist, medical specialist, and dental specialist) according to their specialty and authority [11].

However, behind the rapid growth of beauty clinic, it actually has negative aspects, among others. As the consumers have paid expensively the beauty product and the service, but, they develop complications in their use, thereby they exacerbate their skin condition. In accordance with the Law of consumer protection in Indonesia, the businessmen are responsible for the consumer products and services [12]. For example, studies have indicated that some short-term anti-aging hormone treatments can have adverse effects such as diabetes and glucose intolerance [13], and that long-run administration of growth hormone to older persons may potentially elevate the risk of cancer [14].

\subsection{Constitutional Right Responsibility}

Citizens' constitutional right should be guaranteed in the constitution as the form of human right recognition and there should be an independent court not affected by the ruler and the government's action should be based on the law. In relation to the esthetic beauty clinic practice, the law protection, the citizens' constitutional right implementation and the enforcement that should be fulfilled by state and beauty clinic, are the rights to the law protection and certainty guarantees and to health as well as healthcare service [15]. Those rights and freedoms are included in the 1945 Constitution and some of them are included only in the law but have quality equally important constitutionally or called "constitutional importance" as mentioned explicitly in 1945 Constitution [16]. Corresponding to social contract principle, every citizen-related right is, has a reciprocal relation to the state's obligation to fulfill it. Similarly, the constitutional authority of the state has through its organs is also related reciprocally to the constitutional obligation that should be obeyed and complied with by every citizen.

Constitutional right protection and enforcement are all stakeholders' obligation. Constitutional right not only involves right, but also pertains to obligation, the obligation to respect and to appreciate each other's constitutional right. Thus, there are restriction and prohibition in the implementation of constitutional human right protection. The restriction specified by the law is intended to ensure the recognition of and respect to others' right and freedom, and to meet demand.

\section{Objective of Study}

The objective of research is to study the responsibility of government and esthetic beauty clinic in fulfilling the citizens' constitutional right to service in esthetic beauty clinics in Indonesia.

\section{Methodology}

This research employs an empirical qualitative method. The author collected the primary data through observation study and interviewing the owners, managers, physicians, beauticians, 
nurses, pharmacists, users, and government institutions related to the operation of esthetic beauty clinic. Meanwhile, the secondary data was collected through library study on law, primary, secondary, and tertiary law materials. The research was taken place in ten cities in Indonesia: Central Jakarta, South Jakarta, Karawang, Bandung, Semarang, Surakarta, Madiun, Surabaya, Sleman and Yogyakarta. The data analysis was conducted using evaluative analysis with Lawrence Friedman's legal system theory [17].

\section{Discussion}

Esthetic beauty clinics are organized based on the enacted legislation. The state should give the users of esthetic beauty clinics the law of certainty and protection with good governance and institutionalization.

Roscoe Pound's opinion "law is the tool of social engineering" provides the basis, that is, the law is used as a means of social change, the law must play an active role in engineering social change in society, so the law must be a driving force in the direction of social change to be better than Before. The Developmental Law Theory developed by Muchtar Kusumaatmaja based on the Roscoe Pound theory provides the basis for the functioning of the law as a "Community Renewal Tool" [18].

Esthetic beauty clinic ideally provides safe-service and cosmetic product to users, according to the guideline of esthetic beauty clinic organization in Indonesia and Regulation (EC) No 1223/2009 of The European Parliament of The Council of 30 November 2009 on cosmetic products, Article 9, stating that Cosmetic products should be safe under normal or reasonably foreseeable conditions of use. In particular, risk-benefit reasoning should not justify a risk to human health [19]. Considering the result of research, majority of beauty clinics have profit-oriented principle and some rules of law as well as institutional rules are ignored. Regulation of beauty clinic has been governed specifically in the Guideline of Esthetic Beauty Clinic Organization released by Republic of Indonesia's Health Ministry, and generally there are some other regulations related to health law and consumer protection. The organization of beauty clinic in Indonesia is encircled by the two laws.

The regulation of beauty clinics in health law has been included in Law Number 29 of 2004 about Medical Practice (practicing physicians' authority), Guidelines of Esthetic Beauty Clinic Organization released by Republic of Indonesia's Health Ministry in 2007, Law Number 36 of 2009 about Health (government's responsibility for the fulfillment of health right). Government Regulation Number 32 of 1996 about Health Workers (related to the authorized executive personnel beauticians, nurses, pharmacist), Presidential Regulation Number 72 of 2012 about National Health System (basics of national health development), Health Minister's Regulation Number 363/Menkes/Per/IV/1998 about Health Equipment Examination and Calibration in Health Service media, Health Minister's Regulation Number 269/Menkes/Per/III/2008 about Medical Record (clinic users history recording), Health Minister's Regulation Number 290/Menkes/Per/III/2008 about Informed Consent (needed when there is high-risk and invasive medical action), Health Minister's Regulation Number 411/Menkes/Per/III/2010 about Clinical Laboratory, Health Minister's Regulation Number 001 of 2012 about Individual Health Service Referral System (when there is complication or worsening skin condition), Health Minister's Regulation Number 36 of 2012 about Medical Secret, Health Minister's Regulation Number 46 of 2013 about Health Worker Registration, Health Minister's Regulation Number 9 of 2014 about Clinic, Provincial and City/Regency Local Regulation related to beauty clinic license and operation.

The regulation related to beauty clinics has also mentioned in consumer protection laws including Law Number 8 of 1999 about consumer protection, Republic of Indonesia's Government Regulation Number 57 of 2001 about National Consumer Protection Agency, Presidential Regulation Number 80/2017 about Food and Drug Administration, Health 
Minister's Regulation Number 1176/MENKES/PER/VIII/2010 about Product Notification, Republic of Indonesia's Government Regulation Number 58 of 2001 about Consumer Protection Implementation Building and Supervision, and Republic of Indonesia's Government Regulation Number 59 of 2001 about Community Self-Help Consumer Protection Institution.

The result of the research shows there is a responsibility involving esthetic beauty clinic practice and the responsibility falls down to the government as the rule developer and the one dealing with esthetic beauty clinic organization affairs and the most essential responsibility lies on the esthetic beauty clinic management conducting practice and providing service. Considering the guideline of esthetic beauty clinic organization published by Esthetic Beauty Clinic Directorate General, government's responsibility for esthetic beauty clinic practice lies on licensing, building, supervision, monitoring and evaluation of the beauty clinic operation in order to ensure the best service.

The form of other government's responsibility lies on Industrial and Trade Ministry relates to the production of drugs, cosmetics and equipments used, Nuclear Power Supervising Agency (Badan Pengawas Tenaga Nuklir, thereafter called Bapeten) related to nuclear power use, Food and Drug Administration (Badan Pengawas Obat dan Makanan, thereafter called BPOM) related to drug and cosmetic circulation, Indonesian Islam Scholar Chamber (Majelis Ulama Indonesia, thereafter called MUI) related to halal (rightful) status of drug and substance used, National Consumer Protection Agency (Badan Perlindungan Konsumen Nasional, thereafter called BPKN) related to consumer protection, General Court and Consumer Dispute Settlement Agency (Badan Penyelesaian Sengketa Konsumen, thereafter called BPSK) for settling its settlement, and One-Stop Licensing Service Agency (Badan Pelayanan Terpadu Satu Pintu, thereafter called BPTSP) for licensing and Health Service for supervision and building at city/regency level.

Considering Articles 19-21 of Consumer Protection Law, the responsibility of beauty clinic business consists of firstly responsibility based on fault, when there is a procedure fault in diagnosis, action, and drug administered, the performer of beauty clinic business should be responsible for the loss the consumers suffer from; secondly, the responsibility for risk or action taken, for example the action that will result in side effect such as laser or other operative media action; thirdly, the responsibility for the product, namely drug and substance received during the treatment process in beauty clinic; and fourthly, the professional responsibility, meaning that there is an authorized health workers that can take action in esthetic beauty clinics.

The result of the research shows that the executors of medical service in beauty clinics are physicians without competency for certain medical action (specialist action); types of services provided in beauty clinic are lightening injection and infusion, acne treatment and medication, body slimming/firming, chemical peeling, microdermabrasion, jet peel, cauter, oxygen therapy, mezotherapy, and LAT; types of equipment provided in beauty clinic are slimming, cauter, microdermabrator, Laser, IPL and sophisticated-technology cosmetics; majority homogeneity of chemicals combined with cream/drug use mercury and hydroquinone as instantaneous skin-lightening substance, medical record and non-orderly informed consent, Government's institution giving beauty clinic operation license not synchronous with other region. This condition certainly harms the consumers, for example mercury hazard.

Mercury is a metal that is a liquid at room temperature. Mercury has a long and interesting history deriving from its use in medicine and industry, with the resultant toxicity produced. In high enough doses, all forms of mercury can produce toxicity. The most devastating tragedies related to mercury toxicity in recent history include Minamata Bay and Niagata, Japan in the 1950s, and Iraq in the 1970s. More recent mercury toxicity issues include the extreme toxicity of the dimethylmercury compound noted in 1998, the possible toxicity 
related to dental amalgams, and the disproved relationship between vaccines and autism related to the presence of the mercury-containing preservative, thimerosal [20].

\section{Conclusions}

The responsibility of government related to esthetic beauty clinic as mentioned in legislations of health sector, particularly the guideline of esthetic beauty clinic organization and the consumer protection law, the state organs authorized in organizing esthetic beauty clinic related to beauty clinic, and the authorized institutions related to beauty clinic such as Health Ministry includes supervising, building, monitoring and evaluation, drug production and cosmetics and equipment used, nuclear power use, drug and cosmetic circulation, halal status of drug and substance used, consumer protection, dispute settlement, and licensing and supervision and building at city/regency level. Meanwhile, the responsibility of esthetic beauty clinic involves fault, risk, product and professional.

\section{References}

1. Law Number 39 Year 1999 concerning Human Rights

2. Law Number 36 Year 2009 concerning Health

3. http://www.un.org/en/universal-declaration-human-rights/ accessed in 10 August 2018

4. https://www.ohchr.org/Documents/ProfessionalInterest/cescr.pdf accessed in 11 August 2018

5. N. C. Rosaly, C. de-Araujo. Consumers and Clinical Decision Support, Clinical Decision Support (Second Edition) (The Road to Broad Adoption, San Diego, 2014)

6. R. Went, Globalization: Myths, Reality, and Ideology, The EU in a Globalized World, (M. E. Sharpe.Inc, New York, 1997).

7. A. G. Bryan, Black Law Dictionary, (West Publishing, St. Paul, 2004)

8. D. Oughton, J. Lowry, Text Book a Consumer Law, (Blackstone Press Limited, London, 1997)

9. B. S. Atiyeh, M. Kadry, S. N. Hayek, R. S. Musharafieh, Aesthetic Surgery and Religion: Islamic Law Perspective, Published online: 30 October 2007 (Springer Science, Business Media, LLC 2007)

10. R. Yaman, Z. Alias and N. M. Ishak, Beauty Treatment and Spa Design from Islamic Perspective, Procedia - Social and Behavioral Sciences 50 (2012) 492 - 501, AcE-Bs 2012 Bangkok ASEAN Conference on Environment-Behaviour Studies, Bangkok, Thailand, 16-18 July 2012,

11. General Directorate of Medical Services Development. Ministry of Health of Republic of Indonesia, Pedoman Penyelenggaraan Klinik Kecantikan Estetik Indonesia, (Departemen Kesehatan, Jakarta, 2007).

12. Y. Shofie, Tanggung Jawab Pidana Korporasi dalam Hukum Perlindungan Konsumen, PT Citra Aditya Bakti : Bandung, P. 183

13. National Institute on Aging. Looking for the Fountain of Youth? Retrieved July 3, 2002, from http://www.nia.nih.gov/health/ads/ fount1.git

14. Blackman MR, Sorkin JD, Munzer T, et al. Growth hormone and sex steroid administration in healthy aged women and men: a randomized controlled trial. JAMA. 2002

15. J. H, Vanderschueren DMOI. ejog. 2000.

16. J. Asshiddiqie, Konstitusi And Konstitusionalisme Indonesia, Revised Edition, (Konstitusi Press, Jakarta, 2005). 
17. L. M. Friedman, The Legal System: A Social Science Perspective (New York: Russel Sage Foundation, 1975).

18. A. Manan. Peranan hukum dalam pembangunan ekonomi,, (PT. Kencana. Jakarta,2014).

19. Regulation (EC) No 1223/2009 Of The European Parliament And Of The Council of 30 November 2009 on cosmetic products, P.1

20. Jack C. Clifton II, MD, Mercury Exposure and Public Health, Great Lakes Center for Children's Environmental Health, John H. Stroger, Jr. Hospital of Cook County, Chicago, IL, USA. April 2007Volume 54, Issue 2, Pages 237.e1-237.e45. journal Pediatric Clinics of North America 